\title{
Brand and line extensions: an empirical study from the new age luxury industry
}

\author{
Ashok Som* \\ ESSEC Business School, \\ Avenue Bernard Hirsch - B.P. 105, \\ 95021 Cergy-Pontoise Cedex, France \\ Email: som@essec.edu \\ *Corresponding author
}

\section{Naja Pape}

Copenhagen Business School, Solbjerg Plads 3, 2000 Frederiksberg, Denmark Email: naja_pape@hotmail.com

\begin{abstract}
Brand and line extensions represent an essential vehicle for growth and are currently one of the most applied marketing strategies within the luxury sector. Though it has its advantages, there are several risks associated with pursuing such a strategy. Consequently, this paper attempts to understand the key success factors behind brand and line extension in the new era of luxury expansion. An integrative model of key success factors is proposed by combining current research with empirical findings obtained through an explorative and qualitative research design based on primary data from eight semi-structured interviews with managers from luxury brands. We identify five key success factors: 1) add value through originality; 2) stay at the level of the brand regarding price, quality, style and image; 3 ) create relevance to core business and be aligned with DNA; 4) stick to the vision of the founder; 5) assure consistency in brand identity and image.
\end{abstract}

Keywords: brand and line extension; key success factors; new age luxury; luxury brand growth; the future of luxury; empirical study; qualitative research; institutional perspective.

Reference to this paper should be made as follows: Som, A. and Pape, N. (2015) 'Brand and line extensions: an empirical study from the new age luxury industry', Luxury Research J., Vol. 1, No. 1, pp.18-39.

Biographical notes: Ashok Som is a Professor in the Management Department at ESSEC Business School. His expertise is in global strategy and re-designing organisations. He is the author of the books The Road to Luxury: The Evolution, Markets and Strategies of Luxury Brand Management (Wiley, 2015), International Management: Managing the Global Corporation (McGrawHill, 2009) and Organization Re-design and Innovative HRM (Oxford University Press, 2008). His current research is on creative industries focusing on luxury, movie and art industry. 
Naja Pape received her MSc in International Marketing and Management from Copenhagen Business School. During her studies, she did an exchange at ESSEC Business School where she specialised in the luxury industry and global strategy. She has worked as Chargé d'Étude for Scabal and is currently working as Chef de Marques Internationales for big luxury clients at OMD Paris.

This paper is a revised and expanded version of a paper entitled 'Brand and line extensions: an empirical study from the new age luxury industry’ presented at the 2015 Global Fashion Management Conference 'Renaissance of Marketing and Management in Fashion’, Florence, 26 June 2015.

\section{Introduction}

All companies have a desire to create growth in order to augment profits: "To increase total long-run profits of the enterprise [...] is therefore equivalent to increasing the long-run rate of growth” [Penrose, (1959), p.30]. Luxury brands are no exception. With a current estimated market size of $€ 223$ billion in 2014 and a forecasted annual growth rate of 4\%-6\% until 2017 (D'Arpizio et al., 2014), the personal luxury industry is immense and offers great growth potential. Nevertheless, due to the emergence of a "new normal" in the aftermath of the economic crisis in terms of a maturing global market and an increasingly consolidated market place, brands cannot only rely on market booms as a means to growth (Fondazione Altagamma, 2014). Instead, future growth will mainly be propelled by selling higher volumes and increasing price points (Achille, 2014), for example by diversifying into new product categories (Reddy et al., 2009), product markets or industries (Ansoff, 1988).

Brand extension represents an essential vehicle for growth and is currently one of the most applied marketing strategies within the luxury sector (Springen and Miller, 1990; Riley et al., 2004; Hagtved and Patrick, 2009; Albrecht et al., 2013; Kapferer and Tabatoni, 2013). It is even claimed that the use of brand extensions originates from luxury brands' early diversification into perfume, cosmetics and accessories (Stankeviciute and Hoffmannm, 2011).

Global brands such as Hermès (2014) and Louis Vuitton (2014), once famous for their production of harnesses and trunks, respectively, have extended beyond their core business by adding ready-to-wear, watches and jewelry, perfume, and, for Hermès' part, even tableware and furniture, to their product portfolios. Former specialist brands Dior and Prada (2014) have besides from developing into fully-fledged luxury brands taken it one step further by venturing into non-traditional categories such as cell-phones (Harrods, 2012). Bulgari (2014) and Baccarat (2014) are pursuing new business opportunities in the hospitality sector by opening hotels in locations such as Milan, London, New York and Bali, thus tapping into the growing experiential luxury market. Armani offers an entire universe of products ranging from fashion apparel, perfume and cosmetic to lifestyle categories such as furniture, restaurants, spas, coffee, bathroom and kitchen concepts (Stankeviciute and Hoffmann, 2011; Dauritz and Tochtermann, 2012). 
Though brand extension has its advantages in terms of, e.g., faster growth (Albrecht et al., 2013), development of product assortment (Kapferer and Tabatoni, 2013), lower introduction costs (Tauber, 1988; Keller, 2003), increased consumer acceptance (Tauber, 1988), market share (Smith and Park, 1992; Reddy et al., 1994), sales and profit (John et al., 1998), brand image (Aaker, 1991; Balanchander and Ghose, 2003), brand awareness (Stankeviciute and Hoffmann, 2010) and customer loyalty, there are several risks associated with pursuing such a strategy (Park et al., 1993; Jacobson and Lane, 1997; Hagtved and Patrick, 2009; Srivastava et al., 2012; Albrecht et al., 2013).

The fundamental strategic challenge consists of balancing the inherent tension between a luxury brand's heritage, new product development and growth (Vigneron and Johnson, 2004; Keller, 2009). Brand extensions challenge the trade-off between exclusivity and accessibility as higher volumes risk destroying the "dream value" through over-diffusion (Dubois and Paternault, 1995). As expressed by Bernard Arnault, Chairman and CEO of LVMH: "Some brands [...] have slid off the map of prestigious goods to become a sort of mass market luxury items" [The Economist, (2003), p.67 referred in Riley et al., (2004), p.41]. This potential dilution of the parent brand (John and Loken, 1993; John et al., 1998; Stegemann, 2006; Hagtved and Patrick, 2009; Keller and Sood, 2012) cannot only lead to loss of exclusivity (Pitta and Katsanis, 1995), but also to a reduced perception of quality (Aaker and Keller, 1990; Dacin and Smith, 1994; Völckner and Sattler, 2006) and decreased profitability (Jacobson and Lane, 1997; Reddy et al., 2009).

\subsection{Research gap: the relevance of the study}

Throughout the past two and a half decades a considerable amount of theoretical and empirical research has contributed to the development of an important body of knowledge on brand and line extensions for non-luxury brands (e.g., Aaker and Keller, 1990; Broniarczyk and Alba, 1994; Bhat and Reddy, 2001; Czellar, 2003; Völckner and Sattler, 2006, 2007; Milberg et al., 2013).

These studies have generated important insights into a number of areas of the process of consumers' attitudes towards and evaluations of brand extensions, e.g., brand and category-level fit (Boush et al., 1987; Broniarczyk and Alba, 1994; Bhat and Reddy, 2001; Park et al., 1991; Lau and Phau, 2007; Milberg et al., 2013), the effect of prior knowledge of the extension category or the brand (Boush and Loken, 1991; Bottomley and Holden, 2001), forward and reciprocal spillover effects between parent and extension (Jacobson and Lane, 1997; Balachander and Ghose, 2003), consumer motivation and expertise (Broniarczyk and Alba, 1994), advertising and marketing strategy (Balanchander and Ghose, 2003; Dens and De Pelsmacker, 2010) and purchase intention (Lane, 2000; Bhat and Reddy, 2001). As pointed out by Czellar (2003), the vast majority of existing research focuses thus on consumer characteristics, predominantly rooted in cognitive psychology (e.g., Aaker and Keller, 1990; Park et al., 1991; Broniarczyk and Alba, 1994; Bhat and Reddy, 2001; Monga and John, 2010), and pays little attention to other factors such as consumer heterogeneity, competitor and distributor activity. Moreover, only few scholars have investigated brand extensions from a managerial perspective such as profitability and the decision-making process (e.g., Riley et al., 2004; Reddy et al., 2009). In general, research neglects external factors such as industry structure and the general context. 
As mentioned above, previous research has mainly focused on non-luxury brands. Although some of the overall findings from non-luxury studies seem to be generalisable for luxury brands (Albrecht et al. 2013), insights gained from such studies should be treated with caution as it is widely recognised that luxury brands are inherently different from non-luxury brands (Vickers and Renand, 2003; Völckner and Sattler, 2007; Hagtved and Patrick, 2009). Yet, little research has addressed brand extension specific for luxury brands (e.g., Riley et al., 2004; Hagtved and Patrick, 2009; Reddy et al., 2009; Stankeviciute and Hoffmann, 2011; Magnoni and Roux, 2012; Albrecht et al., 2013) and to our knowledge none of the academic studies conducted at this point in time suggests an integrative approach to investigate the key success factors behind brand and line extensions.

This paper argues that the success of brand and line extension does not mainly depend on consumer characteristics and perceptions and marketing activities, but rather on a number of interdependent internal (e.g., brand strategy) and external factors (e.g., the luxury context) that are considered to be of equal importance to achieve sustainable growth through brand and line extensions.

\subsection{Research question}

In order to ensure brand and line extension success, it is indispensable that managers know how to identify and prioritise the great number of potential success factors. By drawing on the advantages and challenges of brand and line extensions identified in the existing literature outlined in previous sections as well as empirical data, this project aims at investigating the following research question:

What are the key success factors behind the new brand and line extensions in the luxury industry?

This project thus strives to equip luxury managers with the necessary generalisable knowledge for carrying out future brand and line extensions successfully, thereby providing them with a path for long-term sustainable growth.

\section{Theoretical framework}

The study is anchored in an investigation of the distinct nature of luxury (e.g., Dubois and Paternault, 1995; Hagtved and Patrick, 2009; Kapferer and Bastien, 2012) and luxury as an institutional phenomenon (e.g., Meyer and Rowan, 1977; DiMaggio and Powell, 1983, 1991; Granovetter, 1985; Suchman, 1995), creating a solid basis for investigating the interplay between luxury brands and the cultural and institutional context in which they are embedded. Moreover, brand and line extension theory will be applied to identify key success factors. Secondly, methodological considerations are discussed, including reflections upon the chosen research design and data collection process. Lastly, we will conduct a thorough analysis of the interviews before developing the conceptual model for how to grow successfully via brand and line extensions. 
Figure 1 Structure of research (see online version for colours)

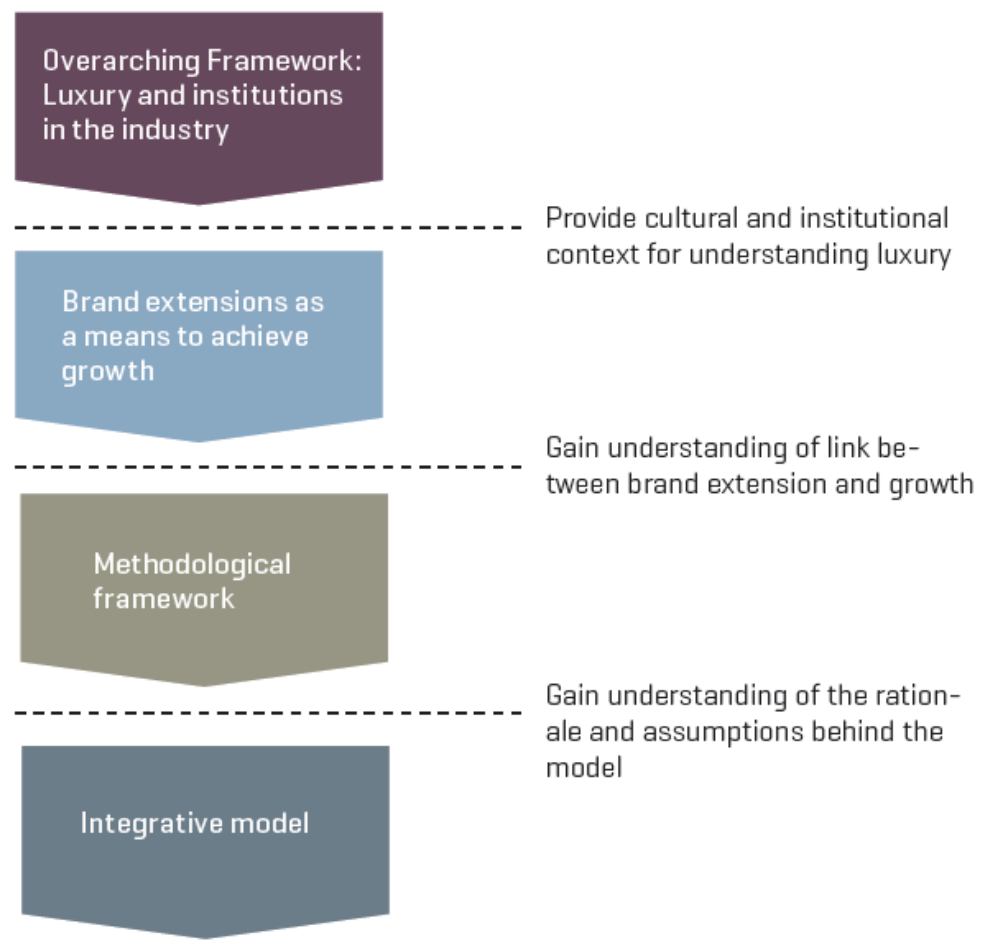

\subsection{The Ins}

The neo-classic economical perspective falls short when analysing the luxury industry. Leading scholars such as Porter (1979, 2008) and Barrney (1995), who are concerned with firms' heterogeneity and variations in industry structure and firm behaviour, seek to develop competitive strategy that enables firms to achieve sustainable competitive advantage through differentiation - either in terms of positioning or the unique combination and employment of resources, respectively. They subscribe to a research paradigm based on assumptions of rationality, market mechanisms and arm's length relationships, but fail to encounter that buying a luxury good is an emotional rather than a rational process: the price far exceeds the functional benefits and the authenticity is worshipped over flawlessness of the product (Kapferer and Bastien, 2012).

Institutional theory, on the other hand, represents a sociological method of studying the idiosyncratic nature of luxury. It rejects the neo-classic paradigm's "atomized, under socialized conception action” [Graanovetter, (1985), p.383] and insists on understanding the social context in which a phenomenon is embedded because "[...] the world is a product of our ideas and conceptions - the socially created and validated meanings that define social reality" [Scott, (1998), p.163]. This implies that economic transactions are conducted within social relations, for which reason one must take into account a number of non-rational factors such as norms, values, social assumptions and "rules of the game", as these are expected to influence the interaction between a brand and its surrounding environment. As a consequence, a brand's structure and strategic choices are a result of a 
socially constructed context where external institutions determine the behaviour of brands: "Organizations are affected, even penetrated, by their environments; but they are also capable of responding to these influence attempts creatively and strategically” [Scott, (2001), p.178].

Institutions do not only define the market opportunities by shaping the opportunity set for individual brands, but shape the formal structure of those brands and the overall industry, meaning institutional fields: “(...) those organizations that, in the aggregate, constitute a recognized area of institutional life: key suppliers, resource and product consumers, regulatory agencies, and other organizations that produce similar services or products” [DiMaggio and Powell (1983), p.148).

Instead of examining the differences between brands, institutional theory aims at understanding the interplay between brands and institutions to uncover the striking similarities within an organisational field in furtherance of analysing the causal relationships, phenomena and processes that exist within the field (Meyer and Rowan, 1977; DiMaggio and Powell, 1983, 1991; North, 1990; Scott, 2001). Although luxury as a concept is absolute and superlative (Kapferer and Bastien, 2012), there are a number of general rules and myths, besides from the mere fact of selling luxury products, that a brand must adhere to in order to be perceived as a legitimate luxury player: e.g., protected titles such as "haute couture", the "Made in..." label, which is in particular important for watches, the desire for handmade, authentic products with a strong heritage and savoirfaire as well as the timeless nature of the products captured in Patek Philippe's iconic advertisement with the tagline "You never actually own a Patek Philippe. You merely look after it for the next generation". Institutional theory thus serves as an instrument to properly define the boundaries of the industry and to understand its underlying mechanisms.

For brands seeking to grow through brand and line extensions it is therefore imperative to understand the regulative, normative and cultural-cognitive institutions inherent in society as legitimacy - or license to operate - only can be gained by adhering to these institutional rules (Meyer and Rowan, 1977; North, 2005). Legitimacy is of paramount importance because it improves the brand's economic performance and hence its chances of surviving (Suchman, 1995; Weber, 1978).

\subsubsection{The institutional paradox and its implications for the strategy of luxury brands}

The institutional rules and rational myths outlined above have become norm and source of legitimacy in the organisational field of luxury, thereby affecting customer demand and driving sales for brands that have incorporated these written and unwritten rules (Meyer and Rowan, 1977). Legitimacy is the most important resource for brands operating in a highly institutional context as it grants access to other resources and improves a brand's chances of survival (Meyer and Rowan, 1977) because "[it] is a generalized perception or assumption that the actions of an entity are desirable, proper, or appropriate within some socially constructed system of norms, values, beliefs, and definitions" [Suchman (1995), p.574]. One of the main challenges that luxury brands face when extending their brand into new product categories is to take the time to establish credibility within this new territory. Marc Puig, CEO of Carrolina Herrera, stresses this point: "Each brand needs to focus on core topics, and do these right, rather than 
branching/branding out too quickly. We want to grasp the full potential before moving into new areas" [quoted in Dauriz and Tochtermann (2012), p.10].

Brands obtain legitimacy through compliance with institutional rules and rational myths (Meyer and Rowan, 1977; DiMaggio and Powell, 1983), which occurs through the process of isomorphism where "[...] organizations may model themselves on other organizations" [DiMaggio and Powell, (1983), p.151] in order to respond to the demands that exist in the institutional context. This imitation can be observed in the way that two of the largest conglomerates within the industry describe their business. LVMH describes the company as "[...] An unrivalled group of powerfully evocative brands and great names that are synonymous with the history of luxury. A natural alliance between art and craftsmanship, dominated by creativity, virtuosity and quality" [LVMH, (2014), p.2] while Richemont underlines that: "Each of Our Maisons represents a proud tradition of style, quality and craftsmanship which Richemont is committed to preserving”

[Richemont, (2014), p.2].

The example demonstrates the institutional paradox: while striving to be unique, LVMH and Richemont become more homogenous due to the myths that "may be felt as a force, as persuasion, or as invitations to join in collusion" [DiMaggio and Powell, (1983), p.150]. The consequence is that not only does the individual brands get more homogenous, the entire field of luxury gets homogenised. In addition, the institutional rules and rational myths such as 'Made in France' and the desire for handmade authenticity are counter-intuitive to efficiency and profit maximisation, which place luxury brands in the dilemma between adhering to these written and unwritten rules or improving efficiency (Meyer and Rowan, 1977; DiMaggio and Powell, 1983; North, 2005). Besides, luxury brands that are isomorphic with the institutional context of luxury also partly surrender internal control: "Organizations whose structures become isomorphic with the myths of the institutional environment [...] decrease internal coordination and control in order to maintain legitimacy" [Meyer and Rowan, (1977), p.340].

In sum, institutional theory's conceptual framework is thus a theorisation of cognitive institutions such as general rules of the game, world view, norms, values, assumptions, ideas and trends, that affect the relation between the luxury brand and the surrounding society (Meyer and Rowan, 1977; DiMaggio and Powell, 1983). As luxury is a highly institutionalised context, it leaves little room for the brand to follow a unique strategy. Those often non-explicated rationales reduce complexity and regulate the behaviour of consumers and brands, but pose a great challenge for companies that wish to grow. Luxury brands can experience a decoupling due to lack of understanding of the new product category in which they expand, a market where they are not embedded in the institutional context.

\subsection{Brand and line extension as a means to growth and brand development}

Drawing on the argumentation that the highly institutionalised context of luxury regulates brands' behaviour by shaping their strategy and the prevalence and importance of brand extension as a popular growth strategy, especially for luxury brands for which it has almost become a business model in itself. It is imperative to understand how successful extensions come to market (Ambler and Styles, 1997). In order to optimise decision-making for future extensions, this section thus investigates the premises of 
success behind brand and line extensions and the unique challenges that luxury brands face.

Brand and line extensions should be based on a common core capability and should contribute to the creation of a diversified, but yet coherent, product portfolio. Christian Dior, for instance, stopped selling stockings, although it was a successful product, because the industrialised production and the requisite distribution strategy, including department stores and wholesale, were not deemed appropriate for the brand. The purpose of a diversified portfolio is to allow the brand a certain flexibility concerning, e.g., trends in the industry and unexpected events in the economical climate (Ansoff, 1988). This indicates likewise that brand and line extensions cannot simply be considered short-term growth boosters, but must be viewed as a part of the long-term process of brand development (Ambler and Styles, 1997).

Following this predominant mantra of growth and brand development leads, however, to a number of paradoxes and dilemmas for luxury brands. First, brand extensions represent a trade-off between exclusivity and accessibility as growth is often created through increased exposure and volume as opposed to the notion of exclusivity, which is usually maintained through limited supply (Dubois and Paternault, 1995; Vigneron and Johnson, 2004). For example, Louis Vuitton and Cartier both suffer from a loss of brand equity in China due to over-exposure and presence in tier three cities (Manager D). As a response, Louis Vuitton implemented a new strategy in 2013 to control growth by boosting the sales of the new top-range of non-logo products (Roberts, 2013, 2014). To avoid this pitfall, Hermès has chosen a radical strategy: "When one of our products gets too successful we stop [selling] it”, Patrick Thomas, former CEO of Hermès [Kapferer (2010) in Kapferer, (2012), p.461]. Accordingly, one of the greatest risks of extending a luxury brand is to kill its cachet owing to the fact that the desirability of a luxury brand is correlated with the difference between brand awareness and brand penetration (Dubois and Paternault, 1995). Second, brand and line extensions link to new product development, which contrasts with the luxury house's heritage (Keller, 2009) - a cornerstone of its raison d'être. Hence, extending a luxury brand does not only include making an irreversible investment, but more important putting the most valuable asset the brand - at stake (Tauber, 1988; Bhat and Reddy, 2001). Research from McKinsey and Co. supports this claim: $61 \%$ of luxury industry experts are afraid of damaging their brands when extending [Dauriz and Tochtermann, (2012), p.9]. In consequence, extending a luxury brand threatens its complex alchemy and legitimacy (Assouly, 2005) for which reason the greatest challenge is to create new products and concepts without loosing the brand's mythical aura of authenticity, uniqueness, craftsmanship and heritage (Dion and Arnould, 2011).

\subsubsection{Key success factors: determinants of brand extension success}

In order to improve brand and line extension success, it is imperative that managers know how to identify and prioritise the great number of factors that lead to either success or failure.

Regardless of the industry and the type of extension, i.e., a vertical line extension (a new product within an existing product category that potentially allows to change the price point) such as Armani Exchange, which is selling for 50\% less than Armani Jeans (Magnoni and Roux, 2012), or a horizontal product category extension (a new product in 
a new category) such as Berluti's ready-to-wear line, two effects influence the extension success. These effects are the forward effect and the reciprocal effect.

The forward effect denotes the effect of the parent brand on the extension (Aaker and Keller, 1990; Park et al., 1991; Pitta and Katsanis, 1995; Albrecht et al., 2013). One of the rationales for using brand extensions is exactly to leverage the brand, meaning that consumers evaluate the extension by using their existing knowledge about the parent brand and the extension category (Aaker and Keller, 1990; Smith and Park, 1992; Broniarczyk and Alba, 1994; Park and Kim, 2001; Sattler et al., 2010) as well as a number of extrinsic cues such as brand name to draw inferences about the brand extension performance (Park et al., 1991; Milberg et al., 2010). The reciprocal effect, on the other hand, is the effect of the brand extension on the parent brand (Aaker and Keller, 1992; Ahluwalia and Gürhan-Canli, 2000; Martínez and Pina, 2010). It is supposed that there exists a causal relation between the consumer evaluation of the extension and the evaluation of the parent brand, meaning that the extension either reinforces the brand's equity in its original category (Aaker and Keller, 1992; Jacobson and Lane, 1997; Balanchander and Ghose, 2003) or dilutes it in the event of extension failure (John and Loken, 1993; Milberg et al., 1997). Consumers' evoked brand extension attitude thus assumes a critical role in shaping long-term brand equity (Salinas and Pérez, 2009); a positive extension evaluation increases the brand equity of the parent brand - both functional and symbolical (Dwivedi and Merrilees, 2013).

\section{Methodology}

The methodology has been adopted to understand two distinctive features. First, this project extends previous studies by developing an integrative model of key success factors behind brand and line extensions. To provide an overview of the complex relationship between the different elements and concepts, it integrates internal factors, such as the brand's decision-making process and brand strategy, and external factors, in terms of the particularities of the luxury context. It takes into account that a company's actions cannot be analysed in a vacuum, but has to be seen in the light of its institutional context (Meyer and Rowan, 1977; DiMaggio and Powell, 1983). It thereby expands the existing linear process-based model (Czellar, 2003) toward a holistic understanding of successful brand extension, thus providing managers with a tool for decision making, which allows for the analysis of prudent allocation of resources.

Second, this project employs an exploratory and qualitative methodological approach as opposed to most of the existing theoretical body consisting of knowledge built on experimental design and statistical modelling (e.g., Boush et al., 1987; Broniarczyk and Alba, 1994; Völckner and Sattler, 2006; Hagtved and Patrick, 2009; Sattler et al., 2010; Magnoni and Roux, 2012; Albrecht et al., 2013). The qualitative method has been chosen to discover alternative perspectives of brand extension, thus revealing new insight benefiting the long-term development of the field (Mick and Fournier, 1999 in Czellar, 2003). In addition some studies are based on fictitious brands, which can be assumed to distort the results (Hem et al., 2003). The importance of this study is enforced by introducing eight case studies based on semi-structured interviews with top managers from trend-setting and well-known luxury brands and a marketing agency. This strong empirical base yields valuable implications in terms of generalisable findings that can be transferred to the personal luxury category as a whole. 


\subsection{The interviews}

Semi-structured face-to face-interviews were conducted in the spring and summer of 2014. The interviews were conducted in English and recorded digitally for later transcription. The details concerning the interview can be found in Table 1.

Table 1 Interview details

\begin{tabular}{|c|c|c|c|c|}
\hline Company & Manager & Date & Duration & Extension \\
\hline $\begin{array}{l}\text { A (Wine and } \\
\text { spirits) }\end{array}$ & A1 & $\begin{array}{l}\text { April 11, 2014, } \\
\text { 19:00 pm }\end{array}$ & 1:01:43 & $\begin{array}{l}\text { Expensive line extensions of the } \\
\text { house's champagne range and } \\
\text { partnerships }\end{array}$ \\
\hline $\begin{array}{l}\text { B (Wine and } \\
\text { spirits) }\end{array}$ & B1 & $\begin{array}{l}\text { April 30, 2014, } \\
\text { 11:00 am }\end{array}$ & $56: 49$ & $\begin{array}{l}\text { Expensive limited edition } \\
\text { champagne and accessories }\end{array}$ \\
\hline $\begin{array}{l}\text { C (Perfume and } \\
\text { cosmetics) }\end{array}$ & $\mathrm{C} 1$ & $\begin{array}{l}\text { May } 19,2014, \\
10.00 \mathrm{am}\end{array}$ & $42: 17$ & Spas, accessories \\
\hline $\begin{array}{l}\text { D (Marketing } \\
\text { agency) }\end{array}$ & D1 & $\begin{array}{l}\text { May 22, 2014, } \\
15: 30 \mathrm{pm}\end{array}$ & $45: 57$ & General discussion about clients \\
\hline $\begin{array}{l}\text { E (Leather } \\
\text { goods and } \\
\text { clothing) }\end{array}$ & E1 & $\begin{array}{l}\text { May 28, 2014, } \\
11: 30 \mathrm{am}\end{array}$ & 1:22:03 & Cell phones, watches, menswear \\
\hline $\begin{array}{l}\text { F (Wine and } \\
\text { spirits) }\end{array}$ & F1 & $\begin{array}{l}\text { June 4, 2014, } \\
\text { 11:30 am }\end{array}$ & 1:19:03 & $\begin{array}{l}\text { High priced limited edition } \\
\text { spirit, introduction of two spirits } \\
\text { and a pop-up bar }\end{array}$ \\
\hline $\begin{array}{l}\text { G (Leather } \\
\text { goods and } \\
\text { clothing) }\end{array}$ & G1 & $\begin{array}{l}\text { June 16, 2014, } \\
\text { 17:00 pm }\end{array}$ & $51: 50$ & $\begin{array}{l}\text { Watches and jewelry, tableware, } \\
\text { furniture, special creations }\end{array}$ \\
\hline $\begin{array}{l}\text { H (Home } \\
\text { objects) }\end{array}$ & H1 & $\begin{array}{l}\text { June 16, 2014, } \\
\text { 13:00 pm }\end{array}$ & $48: 35$ & $\begin{array}{l}\text { Hotels, lighting and personal } \\
\text { accessories }\end{array}$ \\
\hline
\end{tabular}

All the informants chose that the interview took place at their office except for Company $\mathrm{H}$, whose Manager preferred a café. The informants were briefed about the process and confidentiality agreements were signed. During the interviews we asked for clarification whenever we had doubts by asking "Is this what you are telling me?", "Is it correctly understood that...?”.

\subsection{Data processing and analysis}

During the stages of the interview analysis, procedural guidelines were set up. In order to turn the transcripts into findings, interpretation was carried out based on a rigorous part-to-whole analysis.

To begin with, we prepared a document where we selected significant statements and quotations that we afterwards categorised in themes. We examined the data sources for similarities and differences while searching for frequent occurrences and interconnections in the subjects' statements. No attempt was made to find abstract meaning in their statements and efforts were done to avoid forcing these into the predetermined categories arising from the interview guide. Instead, we allowed categories, concepts and patterns to develop out of the data collected and sought for potential explanations for these. We then compared these results with the theoretical constructs mapped out in order search for 
convergences, overlaps and contradictions between the existing theory and our empirical material.

\section{Analysis: key success factors behind brand and line extensions}

The analysis and interpretation presented in Table 2 focus on the dominant logic behind the participating brands' choice of extension and, in particular, the factors that account for their success. In line with the inductive stance of this paper, a data-driven coding approach has been applied, meaning that the analytical concepts have emerged through the part-to-whole analysis of the eight interviews collectively.

Table 2 Logic behind extending

\begin{tabular}{lc}
\hline Motive & Brand \\
\hline Growth & $\mathrm{C}, \mathrm{D}, \mathrm{H}, \mathrm{G}$ \\
Demand from investor & $\mathrm{H}$ \\
Brand development: Brand equity and image & $\mathrm{B}, \mathrm{D}, \mathrm{E}, \mathrm{H}$ \\
Development of product portfolio & $\mathrm{A}, \mathrm{B}, \mathrm{G}$ \\
Respond to competition and meet customer demand & $\mathrm{B}, \mathrm{D}, \mathrm{E}, \mathrm{F}, \mathrm{H}$ \\
Inject contemporaneity & $\mathrm{A}, \mathrm{B}, \mathrm{D}, \mathrm{E}$ \\
Discover the brand & $\mathrm{A}, \mathrm{B}, \mathrm{F}$ \\
\hline
\end{tabular}

The interviewees from company C, D, H and G all explicitly mention growth of the business as the predominant rationale behind brand and line extensions. When asked specifically about H's decision-making process $\mathrm{H} 1$ pointed to the concurrence of the mere search for growth driven by a strong demand from their shareholder, as well as a wish to strengthen the brand equity:

"It is to look for growth, basically. More turnovers, more profit, first of all. Secondly, it is about creating. There is an image part of it as well, meaning creating an entire lifestyle environment around the brand. For $H$, it is [...] making sure that the brand becomes a part of the complete lifestyle, your entire life.”

Regardless of whether one looks upon brand and line extensions as a means of enhancing brand equity or developing the brand universe, the Director of $\mathrm{D}$, stresses the underlying motive very clearly:

"It always boils down to selling more products to more people, but because you're luxury, doing it in a discrete way. You don't want to be overexposed [...] And, it can be about improving your brand equity, absolutely [...] You do that to make more volumes. So it's always about growth whether you look at $\mathrm{LVMH}$, which is known as the hard financial sales company, or whether you're family-owned like Chanel.” 
A well-known example is Hermès that, by building on its existing competence in silk scarves, introduced ties to the male consumers after acknowledging their discontent with the missing offer. For Company F, this identification of consumer needs also turns into a process of market adaptation because the consumption situation and consumer preferences differ from country to country: Chinese often drink cognac with food whereas Americans like mixing it with soda:

\begin{abstract}
"[...] We have brands like FC, which is specific to China and Chinese consumers, young consumers. We have FB, which is almost only for the States with a more round taste than VS. What I mean is that when we approach new territories and new consumers there is a sense of empathy, a sense of listening to the consumers, to what they want. This is also quite important to keep in mind in order to understand what Company $\mathrm{F}$ is vis-a-vis its approach to consumers.”
\end{abstract}

Both Company $\mathrm{F}$ and Company B refer to a wish to comply with consumers' desires by understanding their lifestyle, their values and their needs. They seek to create products and experiences that meet consumers' unsaid needs, e.g., one of Company B's products launched in the USA - a response to Company F's nightclub drink - and products that allow them to express the vision of the brand:

\begin{abstract}
"I need to see what I have and what I am missing [in my product portfolio]. If I am missing products to talk about and to show the vision of the brand, about what the quality [...] stands for, then it's what I am going to launch. If I am missing a product for nightclubs [...], for example, I know that billionaires need big formats to show off in the nightclubs and something visible when it's dark [...]"
\end{abstract}

In the world of luxury, the difference between being anchored in the past and being perceived as passé is a delicate balance difficult to master. Therefore, luxury brands seek to inject contemporaneity to render the brand more relevant. This was exactly the logic behind the re-launch of Company E's menswear brand:

"The logic is that in the fashion world you cannot stand still. You have to move on. [...] We had to move to something more interesting for the new customers and the new countries. Designer S is a very strong character and we needed a strong character to bring a revolution inside Company E."

Although renewal might seem logic for ready-to-wear, it can be observed for other brands such as Company F and A as well. By creating links with the arts, hosting events with philharmonics and publishing books about extraordinary people, they seek to inject dynamism into static products like cognac and champagne.

\title{
5 Identification of success factors
}

After having determined the different motives for extending, we identified five key factors behind brand and line extension success that will be elaborated in Table 3. The focal point is alignment, regardless whether one considers the actual offer, the quality, the vision or the brand identity. 
Table 3 Overview of each brand's position on key success factors

\begin{tabular}{lllllllllll}
\hline Factor & A & $B$ & $C$ & $D$ & $E$ & $F$ & $G$ & $H$ \\
\hline Add value through originality & $\mathrm{X}$ & $\mathrm{X}$ & & & $\mathrm{X}$ & & $\mathrm{X}$ & \\
Stay at level of brand (quality, design, price, image) & $\mathrm{X}$ & & $\mathrm{X}$ & & $\mathrm{X}$ & & $\mathrm{X}$ & \\
Create relevance to core business and & $\mathrm{X}$ & $\mathrm{X}$ & $\mathrm{X}$ & $\mathrm{X}$ & $\mathrm{X}$ & $\mathrm{X}$ & $\mathrm{X}$ & $\mathrm{X}$ \\
alignment with DNA & & & & & & & & \\
Stick to philosophy of the founder/brand & $\mathrm{X}$ & & & $\mathrm{X}$ & $\mathrm{X}$ & $\mathrm{X}$ & $\mathrm{X}$ & $\mathrm{X}$ \\
Assure consistency in brand image and identity & $\mathrm{X}$ & $\mathrm{X}$ & $\mathrm{X}$ & $\mathrm{X}$ & $\mathrm{X}$ & $\mathrm{X}$ & $\mathrm{X}$ & $\mathrm{X}$ \\
\hline
\end{tabular}

The idea of value added through originality about developing something that nobody else has resonates with Company A. House of A was born to propose a level of quality that did not exist and Extension 1 and 2 have added an unparalleled originality and rarity in the product range. This idea concurs with Company G's principles of adding something ambitious and creative when launching a new product illustrates with an example of why the brand is not producing sunglasses:

\begin{abstract}
“At Company $\mathrm{G}$ we have never done any business in sunglasses. Why? A lot of people are proposing us to go into that direction, that field, and there is certainly a lot of money to be made in that business. So why not? First, the policy of Company $\mathrm{G}$ since the beginning, and especially since the beginning of the 20th century, has been never to give any license. As we are a family company and it is our own name [...], G is more than a trademark. It is also a signature, so we are signing all the objects, everything that is sold under our name. We want always to control it $100 \%$. That is the first reason. The second reason is that we believe that $G$ is a very creative company and when we enter into a new sector we need to be creative and be bringing something more, something new, something different to the industry. So going to sell sunglasses if it is just to put [a logo] on the side, it would sell, certainly, but you are not adding anything spectacular to this industry and you are not adding anything ambitious or creative to Company G. So what I mean when saying that the key factor is relevance, in our case, according to our strategy, going to that business through a license agreement - because everybody is doing business in sunglasses through licensing - would not be relevant to our strategy. For me, the key factor is relevance and understanding. I think the wrong approach is to say: "Ok, I want to be a luxury business, the major businesses in that environment are present in a certain number of categories so I go into that categories”. In the end, if you are not bringing something new, something different, I do not think that it is relevant.”
\end{abstract}

Luxury brands are more extendible than non-luxury brands due to their symbolic value and hedonistic promise, which transfers to all products sold under the same brand name (Hagtved and Patrick, 2009). Yet, these brands are also more sensitive to inconsistent brand cues such as difference in price, quality and brand image, which can cause a negative reciprocal effect and hence harm the parent brand. Consequently, Company E's decision-making is to stay at the level of the brand:

"If a new product can strengthen the company with a good image and be produced at the best level of the market in that field, then we can do it, but you always have to be at the top. You cannot have, for example, watches that are at a medium level and then do haute couture or pret-à-porter de luxe. You need to have watches at the same level as the other product ranges and that is what makes brand extensions difficult.” 
Manager A1 also rejects the notion of placing some products as superior to others as has often been the case with Extension 1:

"It [Extension 1] is intense and unique, but you cannot say that it is better than the others [Grande Cuvée, Vintage, Rosé]. The minute you bring something as the best you go against the vision of the founder and the minute you go against this reason of existence and your values, you harm your house."

For Company G, staying at the level of the brand is also incontestable.

"[...] We have never, never considered having a second line. For us, a second line is absolutely not acceptable. We do not understand the concept. There is one Company $\mathrm{G}$ creation, one G quality and if people are willing to pay for that quality you cannot have a line where we say: "Ok, it is $\mathrm{G}$, but it is less expensive, it is less G."

It is necessary to have a profound understanding of the brand before extending in order to bridge the brand identity from the parent to the extension:

"You really have to understand what your brand is about before launching anything. What is your belief? What does the brand stand for? For BP it is beauty, that your life will be much better with beauty. Beauty is changing your life deeply. It is not something superficial. [...] We need to make sure that by launching a new product we will stay with the [visual codes and imagery], and also, that we will respect what we can change and what we can't.”

Brand and line extensions have to be legitimate within the boundaries of the brand, which is often established by being in line with its tradition, heritage and a well-established history. Accordingly, adhering to the founding myth or the philosophy of the founder automatically initiate a certain degree of legitimacy, thereby augmenting the chances of success. At Company F, this manifests itself in their conception of quality, which was one of the founding principles, and in the sustainability and consistency in the taste of their cognac:

"The key word is the quality of the cognac, a sustainable and consistent quality over the years. When I see [the master blender] and ask him to develop a new product he has two immediate questions: "How many bottles?", "Limited edition or part of the range?” If you asked me to do a cognac of any kind it is extremely easy because we have so much stock available, but what is difficult is to create something you will be able to sustain over the years and decades. Take the F XO created in 1870: If the creator came now, he would taste the same flavor as he did in 1870. It is extremely important."

Significantly, this vision of the founder as the main source of inspiration can be found across categories. For example, Monsieur C not only as a source of inspiration, but as a pivot around which the entire business is turning:

"Monsieur C is our raison d'être. His competencies have been carried on from generation to generation and have enabled us to continuously create new amazing products."

New product development can be destabilising for luxury brands as it expands the brand's sphere and can hence have great consequences for the business if not carried out with much consideration and precision. As for Company E, Manager E1 explains:

"To manage the image is the most difficult thing in the world because everything that hurts [your brand], hurts your business... 
Consequently, assuring fit with the brand's symbolic associations is an important factor for succeeding with brand and line extensions, which Manager C1 comments on:

"It has to convey our values to pass on the right message to our clients. We need to have continuity and consistency in our brand appeal and image [...].”

Each brand's identity is constituted by a combination of emblematic symbols such as logos, signs, codes, colours and attributes and other intangibles. Taken together, these emphasise the long-established history and ensure consistent brand cues in such a way that the customer can easily recognise the products and transfer the symbolic value from the parent to the extension. Manager D1 uses Chanel as a best-in-class example:

[If] you need to be recognizable as Chanel, [you need] to ideally have one of these codes because that will create what is called a heuristic, a mental shortcut. If you want to create a mental shortcut into your brand you need to either have e.g., a Camellia flower, tweed or a sissy. These are the main assets that they got to communicate that it's Chanel.”

Nevertheless, the identity should also be emphasised with storytelling to support the construction if the dream. For example, Manager A1 explains that:

"The key is building the dream. What makes you dream is the connection between the brand and the consumer [...] A is priced a lot higher than the average champagne brands, but they [customers] pay the premium because they love the brand and the experience. And when people love the brand, this is the magic. If you try to do it fast, you destroy the dream because there is no way to do fast luxury. Then you harm the brand because you want to push emotions, and you cannot push emotions.”

From the analysis of the empirical data, we found evidence for the five primary success factors stated above. Based on the interpretation and a coupling with theory on the inherent nature of luxury, it can be assumed that these factors are all important to succeed in brand and line extensions. The integrative model combines theoretical insights from the academic literature on brand extensions with the empirical findings outlined above while also accounting for the specificities of the institutionalised context of luxury. The model proposes that successful growth through brand and line extensions depends on the theoretically widely recognised success factors (left box) plus the five success factors identified in the empirical data (centre box) that to the greatest extent possible must apply to any brand extension in question. The model is presented in Figure 2.

Figure 2 Integrative model of key success factors behind brand and line extensions

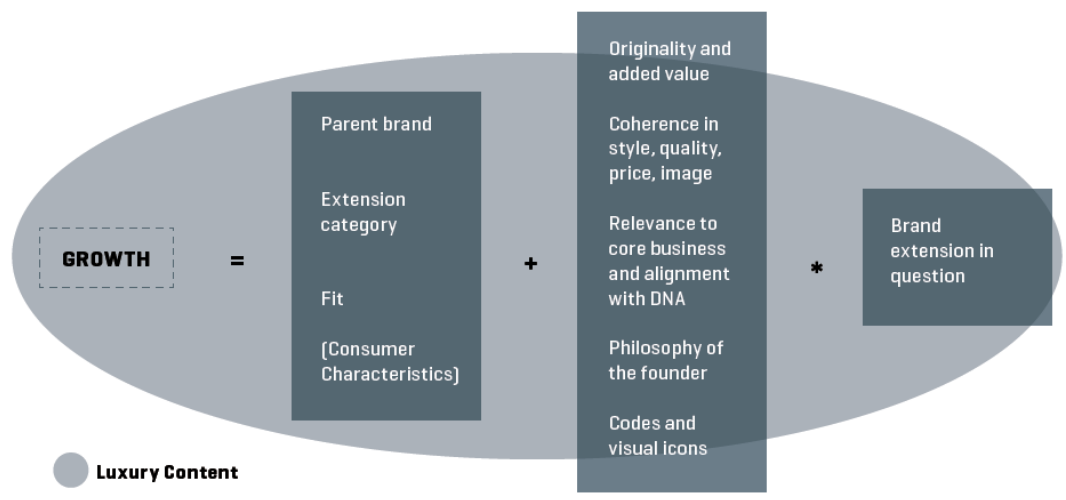




\section{Discussion}

To address the theoretical dimension of the model, previous research has alluded to that successful brand or line extension depends on the four main success factors: the parent brand, the extension category, the fit and the consumer characteristics. However, it can be argued that consumer characteristics are less important in the luxury context due to the reverse power balance between consumer and luxury brand. Consumers follow the brands like loyal devotees (Chad and Husband, 20006), implying that their expertise, involvement in the extension category, innovativeness and perception of risk related to purchase are overruled by the allure of the brand's symbolic value and general hedonistic promise. Thus, when downplaying the importance of consumer characteristics, our analysis clearly reinforces the contention that some of the primary success factors in the luxury industry are the overall perceived fit, the parent brand and the extension category.

For the empirical dimension of the model, our findings strongly emphasise the notion of alignment. While the first empirical success factor - add value through originality - refers to the strength of the creation and the extension category, the remaining four factors strongly accentuate alignment and fit between the parent brand and the extension in terms of extension concept, product category, specific product attributes, previous extensions and resources and capabilities, irrespective of type of parent brand and nature of the extensions investigated. Following this line of argumentation, our findings suggest that:

- the more original and value-adding an extension is

- $\quad$ the more coherent the style, quality, image and price match the brand's existing product range

- $\quad$ the more relevant the extension is to the core business and the DNA

- the more it adheres to the philosophy of the founder

- $\quad$ the more it employs the brand's visual codes

- $\quad . .$. the more successful the extension will be.

Consequently, this research suggests that resources should be allocated to reinforce the alignment process. In addition, resources must be allocated to the development of the creation as a strong creation is even considered a precondition for succeeding.

When comparing the two perspectives we see strong similarities and overlaps between the existing research and empirical data, suggesting the replenishing function of our findings as a type of elaboration of the three factors fit, parent brand and extension category with a predominant emphasis on fit. Further, drawing on the notion of fit and alignment, we significantly see evidence of the importance of consistent brand cues in terms of style, quality, price, image, storytelling, values, heritage, history, tradition and visual icons. This points to the fact that no elements can be disregarded in the world of luxury.

In the framework of institutional theory, the notions of alignment and fit indicate that the brand must follow a number of general "luxury rules" to avoid damaging its 
mysterious aura and to be perceived as a legitimate luxury player, which leaves little room to follow an individual strategy. All this then explains why luxury represents an entirely different approach to understanding the consumer and managing the brand: Buying a luxury product is an emotional decision guided by social processes that attach intangible values to it in order to seduce the customer and spur the dream. Mastering this complex alchemy requires a profound understanding of both the luxury industry and the individual brand.

\section{Conclusions}

To conclude, this paper investigates key success factors behind brand and line extensions in the luxury industry by combining current research with empirical findings into an integrative model that prospectively can be used as a decision-making tool, thus achieving long-term sustainable growth. First of all, this project examines the concept of luxury and its institutional context in order to account for the specificities of this industry. From the analysis of the intrinsic nature of luxury it is evident that luxury represents a radically different attitude to conceptualise the consumer and manage the business. With a price that far exceeds its functional value, buying a luxury product is better thought of as an emotional process. Accordingly, a luxury brands' most important asset is the brand itself, referring to its ability to turn physical objects into dreams and social markers through social processes that attach an abstract meaning to the products. Second of all, this research shows that luxury brands must adapt to the highly institutionalised context in which they are embedded to exploit the great growth potential offered by the personal luxury goods industry. Complying with institutional rules and rational myths such as country-of-origin, authenticity and heritage is indispensable for being recognised as a legitimate luxury actor and hence becoming a part of consumers' consideration set. Third of all, by bridging the current research with our empirical findings, this project identifies five key success factors behind brand and line extensions in the luxury industry:

1 add value through originality

2 stay at the level of the brand regarding price, quality, style and image

3 create relevance to core business and alignment with DNA

4 stick to the vision of the founder

5 assure consistency in brand identity and image.

Significantly, the predominant themes are the alignment between the parent brand and the extension and the extension in itself, which resonates with the existing research on the field. This research thus finds evidence that the more original and relevant an extension is, the better it matches the style, quality, image and price of the brand's existing product range and the more it adheres to the philosophy of the founder and employs the brand's visual codes, the more successful the extension will assumedly be. Consequently, this research suggests that resources should be allocated to reinforce the alignment process, hence protecting luxury brands from over-extension by preparing them for a future of new adventures into adjacent product categories. 


\section{References}

Aaker, D.A. (1991) Managing Brand Equity: Capitalizing on the Value of a Brand Name, The Free Press, New York.

Aaker, D.A. and Keller, K.L. (1990) 'Consumer evaluations of brand extensions', Journal of Marketing, January, Vol. 54, No. 1, pp.27-41.

Aaker, D.A. and Keller, K.L. (1992) 'The effects of sequential introduction of brand extensions', Journal of Marketing Research, February, Vol. 29, No. 1, pp.35-50.

Achille, A. (2014) True Luxury: Global Consumer Insight, Boston Consulting Group [online] http://www.bcg.it/documents/file156204.pdf (accessed 1 October 2014).

Ahluwalia, R. and Gürhan-Canli, Z. (2000) 'The effects of extensions on the family brand name: an accessibility-diagnosticity perspective', Journal of Consumer Research, Vol. 27, No. 3, pp.371-381.

Albrecht, C.M., Backhaus, C., Gurzki, H. and Woisetschläger, D.M. (2013) 'Drivers of brand extension success: what really matters for luxury brands', Psychology and Marketing, Vol. 30, No. 8, pp.647-659.

Ambler, T. and Styles, C. (1997) 'Brand development versus new product development: toward a process model of extension decisions', Journal of Product and Brand Management, Vol. 6, No. 4, pp.222-234.

Ansoff, H.I. (1988) Corporate Strategy, Revised ed., Penguin Group, London.

Assouly, O. (2005) 'La justification du luxe entre nationalité et simplicité', in Assouly, O. (Ed.): Le luxe - essais sur la fabrique de l'ostenation, pp.203-222, Editions de l’Institut Français de la Mode, Paris, France.

Baccarat (2014) Baccarat Hotel and Residences, New York [online] http://baccaratresidencesny.com/ [28/10 2014).

Balachander, S. and Ghose, S. (2003) 'Reciprocal spillover effects: a strategic benefit of brand extension evaluations', Journal of Marketing, Vol. 67, No. 1, pp.4-13.

Barney, J.B. (1995) 'Looking inside for competitive advantage', Academy of Management Executive, Vol. 9, No. 4, pp.49-61.

Berry, C.J. (1994) The Idea of Luxury: A Conceptual and Historical Investigation, Cambridge University Press, Cambridge.

Bhat, S. and Reddy, S.K. (2001) 'The impact of parent brand attribute associations and affect on brand extension evaluation', Journal of Business Research, Vol. 53, No. 3, pp.111-122.

Bloomberg [online] http://www.bloomberg.com/news/2013-01-31/lvmh-full-yearprofit-increases13-on-gains-in-u-s-and-asia.html (accessed 16 November 2014).

Bottomley, P.A. and Holden, S.J.S. (2001) 'Do we really know how consumers evaluate brand extensions? Empirical generalizations based on secondary analysis of eight studies', Journal of Marketing Research, Vol. 38, No. 4, pp.494-500.

Boush, D.M. and Loken, B. (1991) 'A process-tracing study of brand extension evaluation', Journal of Marketing Research, February, Vol. 28, No. 1, pp.16-28.

Boush, D.M., Shipp, S., Loken, E., Gencturk, E., Crockett, S., Kennedy, E., Minshall, B., Misurell, L., Rochford, L. and Strobel, J. (1987) 'Affect generalization to similar and dissimilar brand extensions’, Psychology and Marketing, Vol. 4, No. 3, pp.225-237.

Broniarczyk, S.M. and Alba, J.W. (1994) 'The importance of the brand in brand extension', Journal of Marketing Research, Vol. 31, No. 2, pp.214-228.

Bulgari (2014) 'Bulgari hotels and resorts' [online] http://www.bulgarihotels.com/ (accessed 28 October 2014).

Chada, R. and Husband, P. (2006) The Cult of the Luxury Brand: Inside Asia's Love Affair with Luxury, Nicholas Brealey International, London, UK.

Czellar, S. (2003) 'Consumer attitude toward brand extensions: an integrative model and research propositions’, International Journal of Research in Marketing, Vol. 20, No. 1, pp.97-115. 
D’Arpizio, C., Levato, F., Zito, D. and de Montgolfier, J. (2014) Luxury Goods Worldwide Market Study Fall-winter 2014. The Rise of the Borderless Consumer, Bain and Company [online] http://www. bain.com/bainweb/Publications/luxury-report.asp (accessed 10 January 2015).

Dacin, P.A. and Smith, D.C. (1994) 'The effect of brand portfolio characteristics on consumer evaluations of brand extensions', Journal of Marketing Research, Vol. 31, No. 2, pp.229-242.

Dauriz, L. and Tochtermann, T. (2012) Luxury Lifestyle: Business beyond Buzzwords, McKinsey and Company, Apparel, Fashion and Luxury Group [online] http://csi.mckinsey.com/knowledge_by_region/global/how_luxury_brands_can_create_a_sens e_of_lifestyle (accessed 10/03 2014).

Dens, N. and De Pelsmacker, P. (2010) 'Advertising for extensions: moderating effects of extension type, advertising strategy, and product category involvement on extension evaluation', Marketing Letters, Vol. 21, No. 2, pp.175-189.

DiMaggio, P.J. and Powell, W. (1983) 'The iron cage revisited: institutional isomorphism and collective rationality in organizational fields', American Sociological Review, Vol. 48, No. 2, pp.147-160.

DiMaggio, P.J. and Powell, W. (1991) 'The new institutionalism in organizational analysis', University of Chicago Press, Chicago, USA.

Dion, D. and Arnould, E. (2011) 'Retail luxury strategy: assembling charisma through art and magic', Journal of Retailing, Vol. 87, No. 4, pp.502-520.

Dubois, B. and Paternault, C. (1995) 'Observations: understanding the world of international luxury brands', Journal of Advertising Research, Vol. 35, No. 4, pp.69-76.

Dwivedi, A. and Merrilees, B. (2013) 'Brand extension feedback effects: towards a mediated framework', Journal of Consumer Marketing, Vol. 30, No. 5, pp.450-461.

Fondazione Altagamma. (2014, May 19) 'Altagamma observatory: moderate growth of consumption in 2013 and 2014 - May update', Altagamma Consumer and Retail Insight, Press Release [online] http://www.fondazionealtagamma.it/temp/0106452113146401683file.pdf (accessed 4 June 2014).

Granovetter, M. (1985) 'Economic action and social structure: the problem of embeddedness', American Journal of Sociology, Vol. 91, No. 3, pp.481-510.

Hagtved, H. and Patrick, V. (2009) 'The broad embrace of luxury: hedonic potential as a driver of brand extendibility’, Journal of Consumer Psychology, Vol. 19, No. 4, pp.608-618.

Harrods (2012) 'Luxury Dior phone arrives at Harrods’ [online] http://www.harrods.com/content/the-store/news-events/2012/september/luxury-dior-phonearrives-atharrods (accessed 28 October 2014).

Hem, L.E. and Iversen, N.M. (2003) 'Transfer in brand equity in brand extensions: the importance of brand loyalty', Advances in Consumer Reseach, Vol. 30, No. 1, pp.72-79.

Hermès (2014) 'Les ailes’ [online] http://lesailes.hermes.com/fr/fr/ (accessed 28 October 2014).

Jacobson, R. and Lane, V. (1997) 'The reciprocal impact of brand leveraging: feedback effects from brand extension evaluation to brand evaluation', Marketing Letters, Vol. 8, No. 3, pp.261-271.

John, D.R. and Loken, B. (1993) 'Diluting brand beliefs: when do brand extensions have a negative impact?’, Journal of Marketing, July, Vol. 57, No. 3, pp.71-84.

John, D.R., Loken, B. and Joiner, C. (1998) 'The negative impact of extensions: can flagship products be diluted?', Journal of Marketing, January, Vol. 62, No. 1, pp.19-32.

Kapferer, J. N. (2012) 'Abundant rarity: the key to luxury growth', Business Horizons, Vol. 55, No. 5, pp.453-462.

Kapferer, J.N. and Bastien, V. (2012) The Luxury Strategy - Break the Rules of Marketing to Build Luxury Brands, 2nd ed., Kogan Page, London.

Kapferer, J.N. and Tabatoni, O. (2013) 'Research paper. The LVMH-Bulgari agreement: changes in the luxury market that lead family companies to sell up', Journal of Brand Strategy, Vol. 1, No. 4, pp.389-402. 
Keller, K.L. (2003) Strategic Brand Management: Building, Measuring and Managing Brand Equity, 2nd ed., Prentice Hall, Upper Saddle River, NJ.

Keller, K.L. (2009) 'Managing the growth tradeoff: challenges and opportunities in luxury branding', Journal of Brand Management, Vol. 5, No. 6, pp.290-301.

Keller, K.L. and Sood, S. (2012) 'The effects of brand name structure on brand extension evaluations and parent brand dilution', Journal of Marketing Research, June, Vol. 49, No. 3, pp.373-382.

Koschate-Fischer, N., Diamantopoulos, A. and Oldenkotte, K. (2012) 'Are consumers really willing to pay more for a favorable country image? A study of country-of-origin effects on willingness to pay', Journal of International Marketing, Vol. 20, No. 1, pp.19-41.

Lau, K. and Pau, I. (2007) 'Extending symbolic brands using their personality: examining antecedents and implications towards brand image fit and brand dilution', Psychology and Marketing, Vol. 24, No. 5, pp.421-444.

Louis Vuitton (2014) World of Louis Vuitton [online] http://uk.louisvuitton.com/enggb/homepage (accessed 28 October 2014).

LVMH (2014) 2013 Annual Report [online] http://www.lvmh.com/investor-relations/ documentation/reports?date=2013 (accessed 18 May 2014).

Magnoni, F. and Roux, E. (2012) 'The impact of step-down line extension on consumer-brand relationships: a risky strategy for luxury brands', Journal of Brand Management, Vol. 19, No. 7, pp.595-608.

Martínez, E. and Pina, J.M. (2010) 'Consumer responses to brand extensions: a comprehensive model’, European Journal of Marketing, Vol. 44, Nos. 7/8, pp.1182-1205.

Meyer, J.W. and Rowan, B. (1977) 'Institutional organizations: formal structure as myth and ceremony', The American Journal of Sociology, Vol. 83, No. 2, pp.340-363.

Milberg, S., McCarthy, M. and Park, C. (1997) 'Managing negative feedback effects associated with brand extensions: the impact of alternative branding strategies', Journal of Consumer Psychology, Vol. 6, No. 2, pp.119-140.

Milberg, S.J., Cuneo, A., Epstein, L.D., Goodstein, R.C. and Sinn, F. (2013) 'Call back the jury: reinvestigating the effects of fit and parent brand quality in determining brand extension success’, Journal of Marketing Management, Vol. 29, Nos. 3-4, pp.374-390.

Milberg, S.J., Sinn, F. and Goodstein, R.C. (2010) 'Consumer reactions to brand extensions in a competitive context: does fit still matter?’, Journal of Consumer Research, Vol. 37, No. 3, pp.543-553.

Monga, A.B. and John, D. (2010) 'What makes brands elastic? The influence of brand concept and styles of thinking on brand extension evaluation', Journal of Marketing, Vol. 74, No. 3, pp.80-92.

North, D. (2005) 'Institutions and the performance of economies over time', in Mènard, C. and Shirley, M.M (Eds.): Handbook of New Institutional Economics, Springer, Dordrecht.

North, D.C. (1990) Institutions, Institutional Change and Economic Performance, 1st ed., Cambridge University Press, USA.

Park, C.W., McCarthy, M. and Milberg, S.J. (1993) 'The effects of direct and associative brand extension strategies on consumer response to brand extensions', Advances in Consumer Reseach, Vol. 20, No. 1, pp.28-33.

Park, C.W., Milberg, S.J. and Lawson, R. (1991) 'Evaluation of brand extensions: the role of product feature similarity and brand concept consistency', Journal of Consumer Research, Vol. 18, No. 2, pp.185-193.

Park, J.W. and Kim, K.H. (2001) 'Role of consumer relationships with a brand in brand extensions: some exploratory findings', Advances in Consumer Research, Vol. 28, No. 1, pp.179-185.

Penrose, E.T. (1959) The Theory of the Growth of the Firm, 3rd ed., Basil Blackwell, Oxford.

Pitta, D. and Katsanis, L. (1995) 'Understanding brand equity for successful brand extension', Journal of Consumer Marketing, Vol. 12, No. 4, pp.51-64. 
Porter, M.E. (1979) 'How competitive forces shape strategy', Harvard Business Review, Vol. 57, No. 2, pp.137-145.

Porter, M.E. (2008) 'The five competitive forces that shape strategy', Harvard Business Review, Vol. 86, No. 1, pp.79- 93.

Prada (2014) 'Prada phone by LG’ [online] http://www.pradaphonebylg3.com/ (accessed 28/10/2014).

Reddy, M., Terblanche, N., Pitt, L. and Parent, M. (2009) 'How far can luxury brands travel? avoiding the pitfalls of luxury brand extension', Business Horizons, Vol. 52, No. 2, pp.187-197.

Reddy, S.K., Holak, S.L. and Bhat, S. (1994) 'To extend or not to extend: success determinants of line extensions', Journal of Marketing Research, Vol. 31, No. 2, pp.243-262.

Richemont (2014) Richemont Annual Report 2013-2014 [online] https://www.richemont. com/investor-relations/reports.html (accessed 10 May 2014).

Riley, F.D.O., Lomax, W., and Blunden, A. (2004) 'Dove vs. Dior: extending the brand extension decision-making process from mass to luxury’, Australasian Marketing Journal, Vol. 12, No. 3, pp.40-55.

Roberts, A. (2013) LVMH to Adjust Vuitton Strategy amid of Stable Leather Sales Growth. Bloomberg, 01/02 [online] http://www.bloomberg.com/news/2013-01-31/lvmh-fullyear-profit-increases- 13-on-gains-in-u-s-and-asia.html (Accessed 16 November 2014).

Roberts, A. (2014) Less is More as Vuitton Stays Top Luxury Brand in Ranking, Bloomberg [online] http://www.bloomberg.com/news/2014-05-20/less-is-more-as-vuitton-staystopluxury-brand-in-ranking.html (accessed 16 November 2014).

Salinas, E.M. and Perez, J.M.P. (2009) 'Modeling the brand extensions' influence on brand image', Journal of Business Research, Vol. 62, No. 1, pp.50-60.

Sattler, H., Völckner, F., Riediger, C. and Ringle, C. (2010) 'The impact of brand extension success drivers on brand extension price premiums', International Journal of Research in Marketing, Vol. 27, No. 4, pp.319-328.

Scott, W.R. (1998) Organizations: Rational, Natural and Open Systems, Sage, London

Scott, W.R. (2001) Institutions and Organizations,Sage, California, USA

Smith, D.C. and Park, W.C. (1992) 'The effects of brand extension on market share and advertising efficiency', Journal of Marketing Research, Vol. 29, No. 3, pp.296-313.

Springen, K. and Miller, A. (1990) 'Sequels for the shelf', Newsweek, July 9, pp.42-43.

Srivastava, K., and Gandhi, R. and Sharma, N. (2012) 'Consumer attitude towards brand-extension incongruity: the moderating role of need for cognition and need for change', Journal of Marketing Management, Vol. 28, Nos. 5-6, pp.652-675.

Stankeviciute, R. and Hoffmann, J. (2010) 'The impact of brand extension on the parent luxury fashion brand: the cases of Giorgio Armani, Calvin Klein and Jimmy Choo', Journal of Global Fashion Marketing, Vol. 1, No. 2, pp.119-128.

Stankeviciute, R. and Hoffmann, J. (2011) 'The slippery slope of brand expansion', Marketing Management, Winter, pp.26-31.

Stegemann, N. (2006) 'Unique brand extension challenges for luxury brands', Journal of Business and Economics Research, Vol. 4, No. 10, pp.57-68.

Suchman, M.C. (1995) 'Managing legitimacy: strategies and institutional approaches', Academy of Management Review, Vol. 20, No. 3, pp.571-610.

Tauber, E. M. (1988) 'Brand leverage: strategy for growth in a cost-control world', Journal of Advertising Research, Vol. 28, No. 4, pp.26-30.

Vickers, J.S. and Renand, F. (2003) 'The marketing of luxury goods: an exploratory study - three conceptual dimensions', The Marketing Review, Vol. 3, No. 4, pp.459-478.

Vigneron, F. and Johnson, L. (2004) 'Measuring perceptions of brand luxury', Journal of Brand Management, Vol. 11, No. 6, pp.484-506. 
Voelker, T.A. (2011) 'Kicking up dust: growth as an irrational market response', Journal of Business Strategies, Vol. 28, No. 1, pp.1-26.

Völckner, F. and Sattler, H. (2006) 'Drivers of brand extension success', Journal of Marketing, April, Vol. 70, No. 2, pp.18-34.

Völckner, F. and Sattler, H. (2007) 'Empirical generalizability of consumer evaluations of brand extensions', International Journal of Research in Marketing, Vol. 24, No. 2, pp.149-162.

Weber, M. (1978) in Roth, G. and Wittich, C. (Eds.): Economy and Society: An Outline of Interpretive Sociology University of California Press, Berkely. 